\title{
Potential ecological and socio-economic effects of a novel megaherbivore introduction: the hippopotamus in Colombia
}

\author{
Amanda L. Subalusky, Elizabeth P. Anderson, Germán Jiménez \\ David M. Post, David Echeverri Lopez, Sebastián García-R. \\ Laura J. Nova León, Juan F. Reátiga Parrish, Ana Rojas \\ SERGIO SOLARI and LuZ F. JiménEZ-SEGURA
}

\begin{abstract}
Introduced species can have strong ecological, social and economic effects on their non-native environment. Introductions of megafaunal species are rare and may contribute to rewilding efforts, but they may also have pronounced socio-ecological effects because of their scale of influence. A recent introduction of the hippopotamus Hippopotamus amphibius into Colombia is a novel introduction of a megaherbivore onto a new continent, and raises questions about the future dynamics of the socio-ecological system into which it has been introduced. Here we synthesize current knowledge about the Colombian hippopotamus population, review the literature on the species to predict potential ecological and socio-economic effects of this introduction, and make recommendations for future study. Hippopotamuses can have high population growth rates $(7-11 \%)$ and, on the current trajectory, we predict there could be $400-800$ individuals in Colombia by 2050 . The hippopotamus is an ecosystem engineer that can have profound effects on terrestrial and aquatic environments and could therefore affect the native biodiversity of the Magdalena River basin. Hippopotamuses are also aggressive
\end{abstract}

Amanda L. SubaluskY* (Corresponding author, (D) orcid.org/0000-0001-88936871) and DAvid M. Post Department of Ecology and Evolutionary Biology, Yale University, 165 Prospect Street, New Haven, Connecticut, 06511, USA E-mail asubalusky@ufl.edu

Elizabeth P. Anderson and Ana Rojas Department of Earth and Environment, Institute of Water and Environment, Florida International University, Miami, USA

Germán Jiménez, Laura J. Nova León and Juan F. Reátiga Parrish Departamento de Biología, Pontificia Universidad Javeriana, Bogotá, Colombia

DAvid Echeverri Lopez Corporación Autónoma Regional de las Cuencas de los Ríos Negro y Nare, Antioquia, Colombia

SEbastián García-R. ${ }^{\ddagger}$ Grupo Mastozoología, Universidad de Antioquia, Medellín, Colombia

Sergio Solari and Luz F. Jiménez-Segura Instituto de Biología, Universidad de Antioquia, Medellín, Colombia

${ }^{*}$ Also at: Cary Institute of Ecosystem Studies, Millbrook, New York, USA ¥Also at: Departamento de Ciencias Biológicas, Universidad de los Andes, Bogotá, Colombia

Received 6 July 2018. Revision requested 11 September 2018.

Accepted 20 December 2018. First published online 20 December 2019. and may pose a threat to the many inhabitants of the region who rely upon the Magdalena River for their livelihoods, although the species could provide economic benefits through tourism. Further research is needed to quantify the current and future size and distribution of this hippopotamus population and to predict the likely ecological, social and economic effects. This knowledge must be balanced with consideration of social and cultural concerns to develop appropriate management strategies for this novel introduction.

Keywords Colombia, ecosystem engineer, Hippopotamus amphibius, introduced species, novel ecosystem, population growth, rewilding, socio-ecological system

\section{Introduction}

Pecies introductions are a major conservation concern, $\checkmark$ presenting complex social and ecological challenges (Ehrenfeld, 2010; Gallardo et al., 2016; Courchamp et al., 2017). Concerns may be particularly pronounced when the species in question is known to have strong effects in its native range. Much literature is focused on the detrimental effects of introduced species, but there has been recent discussion of the potential role of introduced species to replace species lost through extinction (Dembitzer, 2017; Lundgren et al., 2018) and/or contribute to conservation through provision of ecosystem services (Schlaepfer et al., 2011). This discussion reveals the complexity inherent in determining appropriate approaches to manage introduced species (Werner et al., 2006; Kodric-Brown \& Brown, 2007; García-Llorente et al., 2008; Mascaro et al., 2012; Svenning et al., 2016; Svenning \& Faurby, 2017).

A recent introduction of the hippopotamus Hippopotamus amphibius into Colombia brings together many of the major research themes on species introductions. The hippopotamus played an important role in ancient Egyptian symbology, with females representing fertility and males representing chaos (Pinch, 2004). These are apt characterizations, as the species can have powerful and multifarious effects on its environment. In its native 

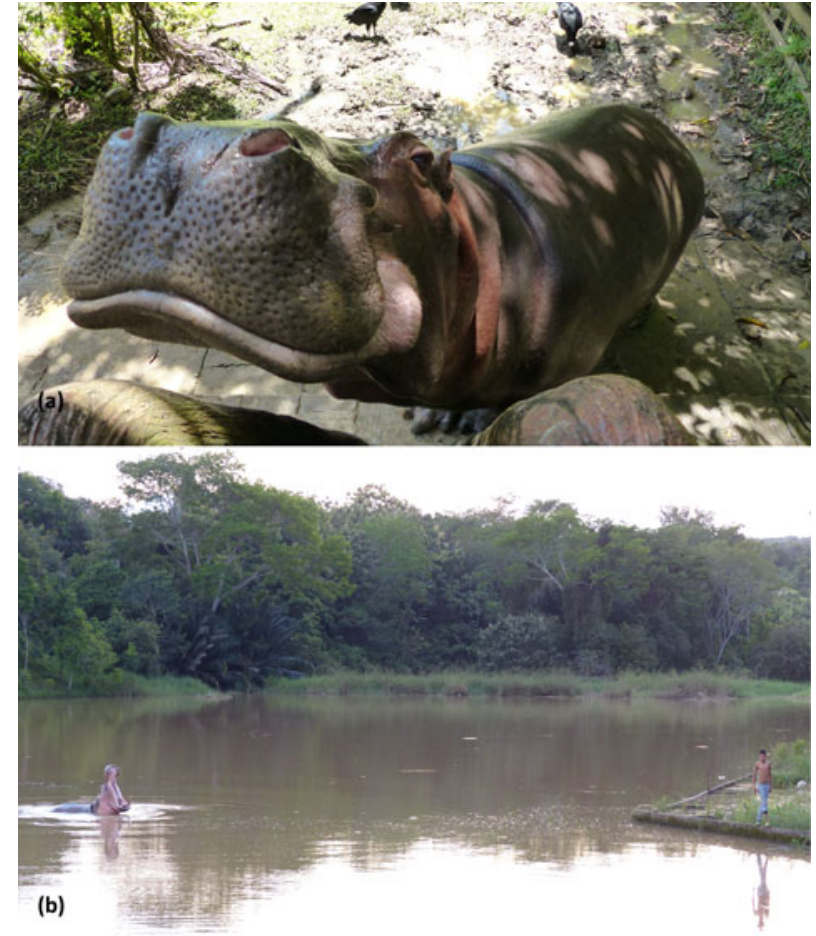

Plate 1 (a) A hippopotamus Hippopotamus amphibius approaching tourists for food at Hacienda Nápoles, and (b) a hippopotamus in a pond outside Hacienda Nápoles.

range the hippopotamus has high rates of reproduction and population growth (Martin, 2005), is an ecosystem engineer that can have strong and complex effects on its environment, and can be dangerous and destructive (Eltringham, 1999). These characteristics have been relatively well-studied in the species' native range, in which population declines as a result of poaching and habitat loss are the primary concerns (Lewison \& Pluhacek, 2017). The recent introduction of hippopotamuses into the wild in the Magdalena River basin of Colombia, the most populated basin in the country, raises questions about how the species will affect this ecosystem and its inhabitants (Dembitzer, 2017; Lundgren et al., 2018).

Here we synthesize the history of this introduction and interventions to date. We provide initial population estimates, predicted growth rates and a range map. We review published literature on the hippopotamus in its native range and in the Magdalena River basin, to discuss the potential ecological and socio-economic consequences of the introduction, and provide recommendations for further study.

\section{Status of the hippopotamus in Colombia}

In 1981 the drug trafficker Pablo Escobar imported four hippopotamuses (three females and one male), amongst other animals, from a zoo in the USA, for his private collection of exotic animals. The hippopotamuses lived in a pond on Escobar's ranch at Hacienda Nápoles (Plate 1). Escobar

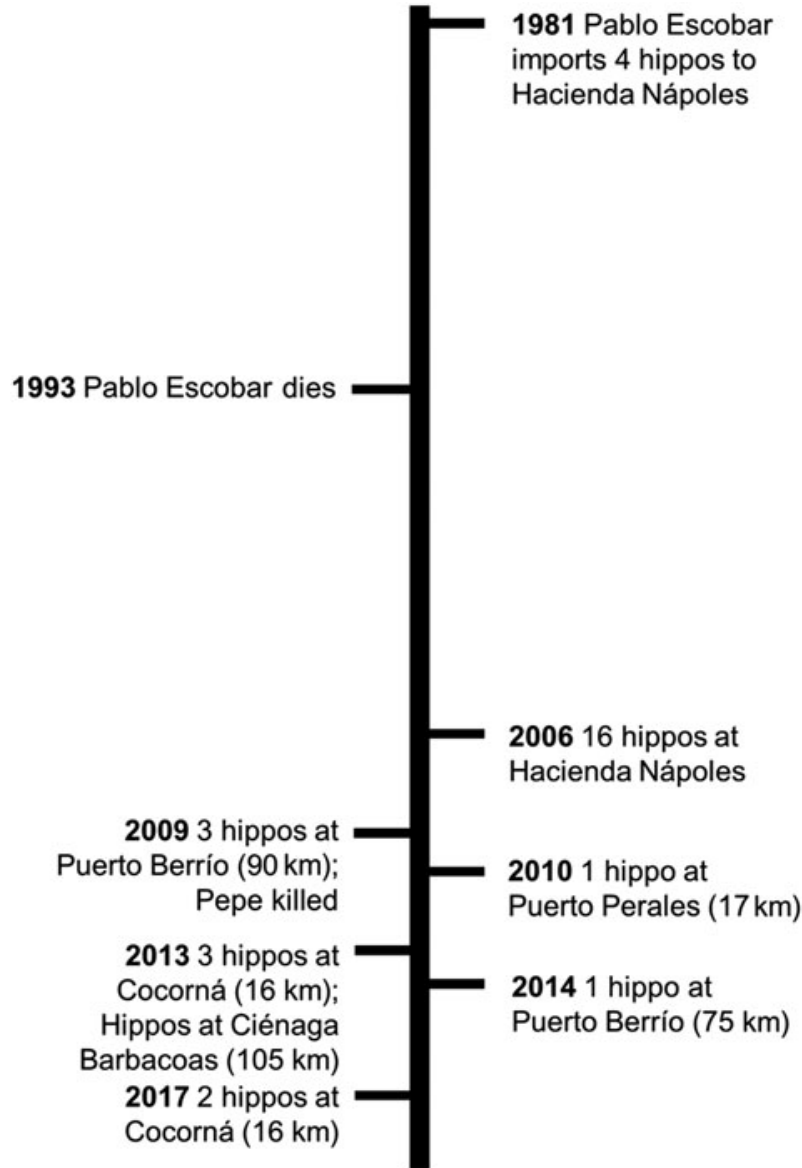

FIG. 1 Timeline of the introduction of the hippopotamus Hippopotamus amphibius to Colombia and dispersal into the Magdalena River basin. Distances in parentheses are straight line distances from Hacienda Nápoles, the point of introduction.

was killed in 1993, and most of the animals were distributed to Colombian zoos. The hippopotamuses, being difficult to transport, were left on the property, where they inhabited one primary pond. Hacienda Nápoles fell into disrepair, but in 2006 it was developed for tourism. By this time, there were an estimated 16 hippopotamuses living on the property. The population continued to grow, spreading into nearby aquatic environments (Fig. 1).

Hacienda Nápoles is located in rolling pastureland near the town of Doradal, $13.5 \mathrm{~km}$ west of the Magdalena River at an altitude of $240 \mathrm{~m}$ (Fig. 2). There are many floodplain lakes (known as ciénagas), man-made cattle ponds, and small streams throughout the landscape, which seem to be facilitating the species' dispersal. In c. 2006 hippopotamuses were observed in ponds near Hacienda Nápoles. In 2009 three hippopotamuses were observed in a ciénaga near the town of Puerto Berrío (c. $75 \mathrm{~km}$ north of Hacienda Nápoles). In 2010 an individual was seen in the main channel of the Magdalena River near the town of Puerto Perales (17 km north). In 2013 three individuals were observed in the Cocorná River, a tributary of the 


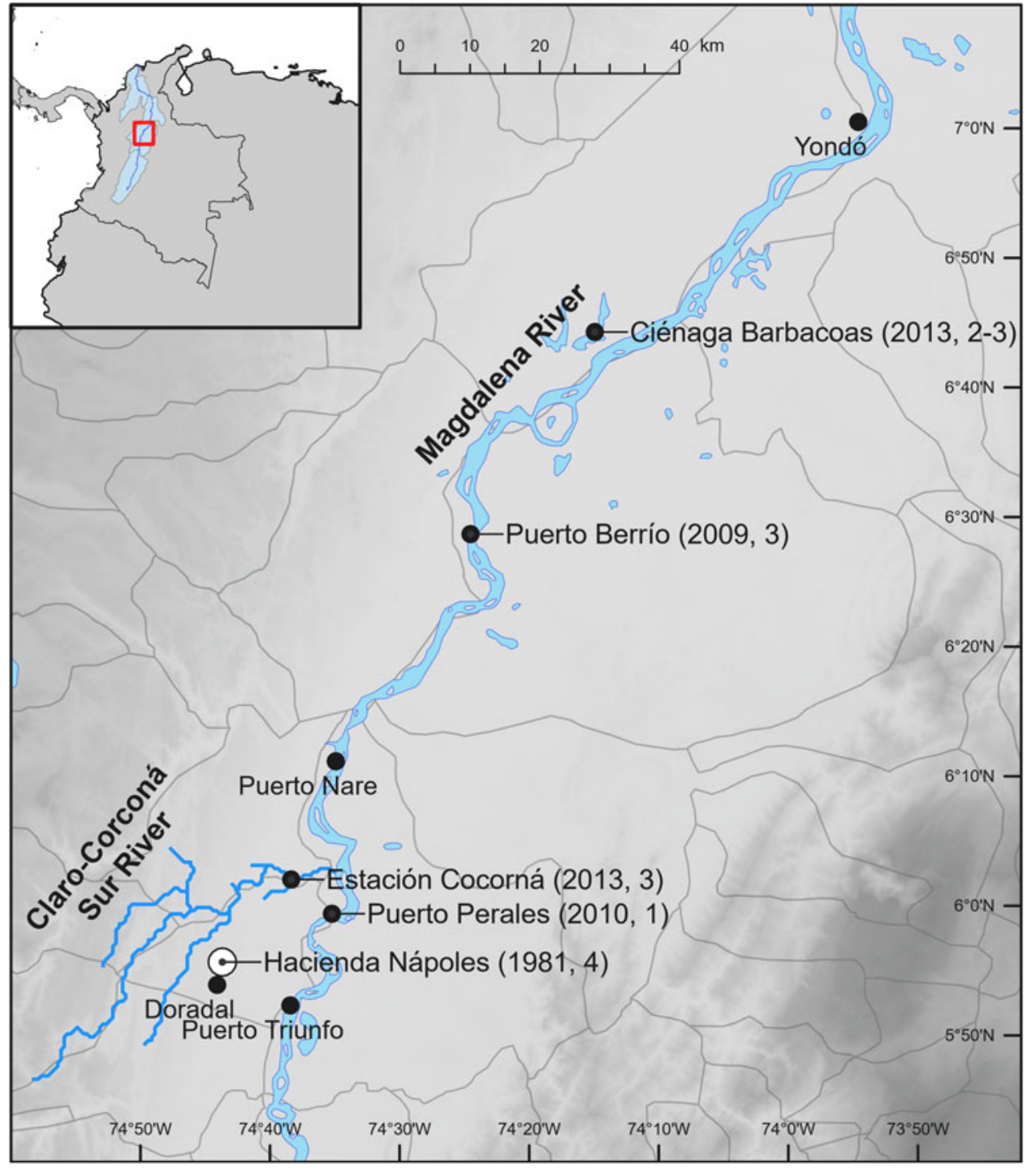

FIG. 2 The currently known range of the hippopotamus in the Magdalena River, with known localities, dates and initial numbers of hippopotamuses observed.
Magdalena River, near the town of Estación Cocorná (16 km north). Hippopotamuses were also seen around that time in Ciénaga Barbacoas (105 km north). In 2014 a hippopotamus was again observed near Puerto Berrío. In 2017 two individuals were seen again near Estación Cocorná over at least 8 months. Although the majority of the hippopotamus population in Colombia is in the main pond near Hacienda Nápoles, these reports raise questions about the potential for this introduced species to spread across a wide swath of the Magdalena River basin.

Across its native range, which extends throughout subSaharan Africa, the hippopotamus is categorized as Vulnerable on the IUCN Red List (Lewison \& Pluhacek, 2017). Populations declined by $7-20 \%$ from the mid 1990 s to the early 200os, and disappeared from some regions, although they may now have stabilized (Lewison \& Pluhacek, 2017). In regions where hippopotamuses have been protected, their populations have rebounded, in large part a result of life history characteristics that promote high population growth rates, particularly at low densities (Martin, 2005; Kanga et al., 2011). Females can become reproductive at 3 years of age and can give birth to a calf every 2-3 years (Laws \& Clough, 1966; Pienaar et al., 1966; Smuts \& Whyte, 1981). The species is long-lived (up to 40-50 years of age), reproductive for decades, and has low mortality, as adults have few predators other than people. Life history tables developed to model hippopotamus population growth upon reintroduction into Namibia showed that populations can grow at an annual rate of $5-11 \%$ (Martin, 2005). In Namibia the population grew at $8 \%$, similar to the rate observed in the Mara River region of Kenya following increased protection of the population since the 1950 s (Kanga et al., 2011). Population growth rates can be particularly high at low densities, as recruitment tends to decline because of competition as populations approach carrying capacity (Chomba, 2013).

There are currently no census data available for the Colombian population, but there are observations from 


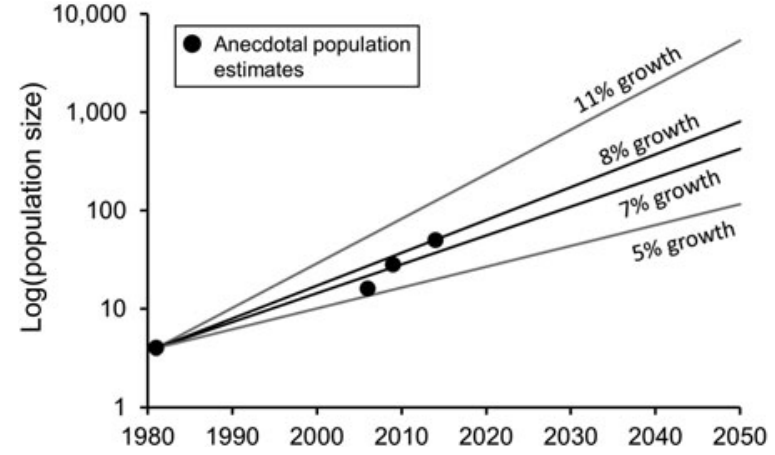

FIG. 3 Range of estimated population growth rates for the hippopotamus population in Colombia, based on an initial population of four individuals and population growth rates documented in low-density hippopotamus populations in Africa, and anecdotal population estimates (DEL, pers. obs.).

people working at Hacienda Nápoles regarding both life history characteristics and population estimates over time. Female hippopotamuses at Hacienda Nápoles become reproductive at 5-6 years of age and can have a calf every 18 months, and there has been little to no mortality among juveniles or adults. Using these traits, the life history models developed for the hippopotamus in Africa suggest the population could be growing at an annual rate of $7-8 \%$, in line with population growth rates observed in other lowdensity hippopotamus populations. Comparing the predictions from this estimated growth rate to population estimates for Colombia at various times over the last 10 years, the data align well, suggesting these are reasonable initial estimates of population growth for this population (Fig. 3). Using the most recent population estimate (40-60 individuals; DEL, pers. obs.) and a constant rate of growth at $7-8 \%$ per year, we estimate there could be 400-80o hippopotamuses in the Magdalena River Basin by 2050. However, a growth rate of nearly $11 \%$ per year is not unrealistic, in which case there could be $>5,000$ hippopotamuses by 2050 .

There are ongoing discussions about who is responsible for the management of the Colombian hippopotamus population. After Escobar's death, the Colombian Dirección Nacional de Estupefacientes (the national drug enforcement agency) took responsibility for his property, but because of a lack of technical expertise with large animals, responsibility for the hippopotamuses was transferred to the environmental authority CORNARE (Corporación Autónoma Regional de las Cuencas de los Ríos Negro y Nare), the provincial authority for management of environment and wildlife in the region encompassing Hacienda Nápoles. The management goal is to halt the growth of the hippopotamus population and relocate them from the wild. Regions in which hippopotamuses have been observed (including Puerto Berrío) also include areas under the jurisdiction of CORANTIOQUIA (Corporación Autónoma Regional del Centro de Antioquia), another regional environmental authority in the Magdalena River Basin.
There have been discussions about which strategies should be used to remove the hippopotamuses from the wild, but management interventions have not been straightforward. In 2009 three hippopotamuses living near Puerto Berrío were reportedly damaging crops and scaring fishers and cattle owners. The government brought in specialists to hunt and kill the hippopotamuses, helped by the Colombian military. A large male hippopotamus, known locally as Pepe, was killed, and a photograph of the team posing with the dead hippopotamus was published, prompting an outcry within Colombia. Animal rights activists took the government to court, and the subsequent ruling banned the killing of hippopotamuses to manage their population. In 2010 a group of 10 Colombian researchers wrote to the government to publicly denounce the ruling, arguing that the hippopotamuses were a large and potentially dangerous non-native species and should be killed before they could spread more widely. Nevertheless, the ruling remained, and surgical sterilization was adopted as the official management strategy. Since 2011 four hippopotamuses have been sterilized (Betancur et al., 2016), but surgical sterilization is expensive and logistically challenging. Hippopotamuses are particularly difficult to tranquilize for capture because they have thick skin, are frequently found in or near water (in which a tranquilized individual could drown), and can be dangerous to people in close proximity (Dembitzer, 2017). The ability of dominant males to mate with multiple females also suggests sterilization will not be effective unless a high proportion of males are castrated. Several individuals have been translocated to zoos but there are a limited number of facilities with sufficient habitat and resources to support them.

\section{Potential ecological effects on the Magdalena River Basin}

The Magdalena River is the largest river system in Colombia, flowing $1,528 \mathrm{~km}$ and draining $262,075 \mathrm{~km}^{2}$ ( $24 \%$ of Colombia's area). The river begins at $3,685 \mathrm{~m}$ in the Andes Mountains and flows north-west through an extensive valley between the eastern and central Cordilleras (Restrepo et al., 2006). Downstream of the convergence of the Magdalena and Cauca Rivers, the main channel flows through an extensive floodplain $\left(22,000 \mathrm{~km}^{2}\right)$, the Momposina depression, and into the Caribbean Sea at Barranquilla. The Magdalena-Cauca has one of the highest sediment yields of the large South American rivers, transporting $184 \mathrm{Mt}$ of sediment to the ocean annually (Restrepo \& Escobar, 2018). The Magdalena-Cauca River basin contains $80 \%$ of Colombia's human population, and there are a number of anthropogenic activities influencing its conservation, including hydropower development, deforestation, urbanization, mining, and livestock and agricultural development (Galvis \& Mojica, 2007; Jiménez-Segura et al., 2016). There are currently 35 dams in the Magdalena-Cauca 
River basin, and plans for additional dams, although further hydropower development is likely to have substantial environmental costs (Jimenez-Segura et al., 2014; Angarita et al., 2018).

The middle Magdalena River has a highly variable flow regime, with peak flows in April-June and OctoberNovember corresponding to the rainy seasons, and low flows in January-February and July-August corresponding to the dry seasons (Restrepo et al., 2006). The hydrological dynamism of this river helps maintain a complex riparian/ floodplain habitat of inter-connected marshes, swamps and channels that connect to the main river channel and exert a regulatory effect on river discharge (Cormagdalena, 2007; Guhl, 2016). Seasonal changes in the river level result in dramatic changes in the connectivity of aquatic habitats and migration of freshwater fishes. Seasonally inundated floodplain lakes, known as ciénagas, provide nursery grounds for 63 native fish species, many of which are threatened (Jiménez-Segura et al., 2010, 2016). As river levels and connectivity decline, fish migrate into the main river channel in search of spawning grounds. This regular migration sustains the most important fishery in the country (Jiménez-Segura et al., 2016).

The middle Magdalena River basin, where the hippopotamuses have been observed, has a warm and humid climate, with a mean annual temperature of $28^{\circ} \mathrm{C}$ and a mean annual rainfall of 2,050 $\mathrm{mm}$. The natural landscape was historically tropical moist forest, c. $75 \%$ of which has been replaced by anthropogenic land use, including human settlements and agro-ecosystems such as palm plantations and livestock pasture (Cormagdalena, 2007, 2013). Nevertheless, the region remains important for floristic (Balcázar-Vargas et al., 2000) and avian biodiversity (Hurd \& Bohórquez, 200o; Laverde-R. et al., 2005), and is home to the Critically Endangered brown spider monkey Ateles hybridus, one of the most threatened Neotropical primates (Aldana et al., 2008; Link et al., 2015a), and the Vulnerable Antillean manatee Trichechus manatus (Deutsch et al., 2008).

Hippopotamuses could have potentially significant ecological effects on the ecosystems of the middle Magdalena River, as they are capable of modifying their physical environment in a way that alters habitat and resource availability for a range of other species (Eltringham, 1999; Moore, 2006; Bakker et al., 2016). Hippopotamuses wallow in aquatic environments, which can include rivers, lakes and wetlands, during the day and at night graze on the adjacent land. An individual can transport $750 \mathrm{~kg}$ dry mass per year of carbon and nutrients from terrestrial to aquatic ecosystems via defecation and excretion (Subalusky et al., 2015). These resource subsidies can influence aquatic productivity in complex ways (Subalusky et al., 2018). Low to moderate levels of resource input may stimulate productivity and provide food resources for aquatic insects and fish (Masese et al., 2015). High levels of input can decrease productivity in benthic environments (Dawson et al., 2016; Stears et al., 2018). These inputs may not be a significant factor at the wholeriver scale in a river the size of the Magdalena, but the effects of such resource loading on aquatic ecosystems can be highly localized because of the tendency of hippopotamuses to aggregate in pools, leading to zones of anoxia and downstream effects (Wolanski \& Gereta, 1999; Dutton et al., 2018). For example, aggregations in ciénagas along the Magdalena River could lead to eutrophic conditions and ultimately anoxic pools, which could be harmful to aquatic life, particularly during low water flow. As ciénagas are nursery grounds for a wide range of aquatic species, even localized zones of poor water quality could have negative effects on aquatic biodiversity and fisheries, particularly when high flows reconnect these anoxic pools to other components of the river system (Dutton et al., 2018).

Hippopotamus movements could have significant effects on the geomorphology and hydrology of the middle Magdalena River by wallowing, scouring and compressing the bottom of pools, increasing the duration for which they hold water (Naiman \& Rogers, 1997). When hippopotamuses move through densely vegetated aquatic habitats they create paths that may form or connect ponds, or that may fill with sediment in subsequent floods, altering hydrological connectivity and geomorphological heterogeneity (McCarthy et al., 1998). These behaviours create habitats that have been shown to benefit fish in African ecosystems, such as the Okavango Delta, by creating deep pools that hold water for long time periods and by increasing hydrological connectivity into backswamp habitats (Mosepele et al., 2009). Such behaviours could influence ciénagas along the middle Magdalena River in a similar way, increasing the duration of inundation and hydrological connectivity with the Magdalena River, which may help maintain open channels and pools that would otherwise be filled with sediment from land-use change. However, the life histories of aquatic plants and animals in this ecosystem are tightly linked to the ecosystem's hydroperiods, and any changes are likely to alter the composition of aquatic plant and animal communities in unpredictable ways. For example, the ecological importance of ciénagas and their macrophyte communities as nursery habitat for larval and juvenile fish partly depends upon their separation from the mainstem channel at low flows and associated protection from other, larger predators; this could be compromised by increased hydrological connectivity with the main river. These habitats also provide important feeding, resting and breeding sites for Antillean manatees (MojicaFigueroa et al., 2014), raising the possibility of intraspecific interactions between these two aquatic species. Hippopotamuses coexist with the African manatee Trichechus senegalensis in West Africa, but we are not aware of any research that has examined interactions between them. 
The movement of hippopotamuses between aquatic and terrestrial habitats creates paths on riverbanks and increases connectivity between riparian and aquatic ecosystems (Naiman \& Rogers, 1997), which may become a conduit for terrestrial nutrients and sediment into the aquatic ecosystem from overland flows (Jacobs et al., 2007), and may also allow expansion of wetlands into the surrounding terrestrial ecosystem (McCarthy et al., 1998). Such movements could expand ciénagas in the middle Magdalena into surrounding habitats utilized by people and livestock, and could influence riparian vegetation by destabilizing riverbanks and altering the hydrological regime.

In terrestrial systems, hippopotamuses alter biodiversity through grazing patterns. Their mouth morphology enables them to graze close to the ground, cropping grass and forbs at their base (Eltringham, 1999). This creates grazing lawns, which influence the species composition of the vegetation and that of ungulates that graze there (Lock, 1972; Kanga et al., 2013). There has been a large degree of conversion from native landcover to agroecosystems in the Magdalena River basin, so it is unlikely hippopotamuses will have a significant effect on the native terrestrial vegetation. However, their focal zones of activity along riparian corridors are important for faunal diversity (Link et al., 2015b; Sandoval-H et al., 2016), which could lead to effects in areas that have escaped conversion. Hippopotamuses also supplement their grazing with aquatic macrophytes when available (Grey \& Harper, 2002), which could negatively impact macrophyte communities in the ciénagas that provide fish nursery habitat.

\section{Potential socio-economic effects in the Magdalena River basin}

The Magdalena River is vital for transport and commerce for a large swath of Colombia. It produces $95 \%$ of the total thermal energy and $70 \%$ of the hydroelectric power generated in the country (Cormagdalena, 2007; Jimenez-Segura et al., 2014). The middle Magdalena was historically important for commercial navigation, but sediment accumulation has reduced the main channel's depth and prevented the navigation of large ships (Cormagdalena, 2013). The majority of artisanal fishing in Colombia is located in the Magdalena basin, with 8,000 artisanal fishers in the middle Magdalena (Cormagdalena, 2007), but the river's fishery has declined since 1970 because of unsustainable fishing practices, construction of reservoirs, and changes in land use resulting in anthropogenic contamination (Cormagdalena, 2007; Galvis \& Mojica, 2007; Jiménez-Segura et al., 2016). Increasing extraction of sand and rocks from the river bed for infrastructure construction is a new challenge for river conservation.

A large proportion of socio-economic development and human livelihoods in the middle Magdalena River basin depends directly upon the river and its waterways (Galvis \& Mojica, 2007), and the further expansion of the hippopotamus into this ecosystem is likely to affect these livelihoods. Hippopotamuses are territorial and aggressive, and could pose threats to fishermen and cascajeros (people who extract sand and rocks from the riverbed), who frequently use the side channels and shallow waterways likely to be favoured by hippopotamuses. Some local people have already changed their behaviour to avoid encounters with hippopotamuses (LJS, pers. obs.).

The species' nocturnal terrestrial foraging, which is typically over 1-2 $\mathrm{km}$ but can be up to 5-10 km inland (Eltringham, 1999), could also have socio-economic effects. In Africa conflict with the species arises from their destruction of agricultural crops, particularly during droughts (Post, 2000; Kanga et al., 2012). Crops cultivated within 5-10 km of the middle Magdalena River and its ciénagas could be at risk, and this would be challenging for small-scale farmers. Hippopotamuses also pose risks to human safety, particularly when they are on land. Across sub-Saharan Africa numerous deaths are attributed annually to the species (Kanga et al., 2012). Any communities living within $10 \mathrm{~km}$ of the current range of the species in Colombia (Fig. 2) need to be educated about the risks and how to avoid them.

At its current density, the hippopotamus may be perceived positively by some people living in the region. Hippopotamuses around Hacienda Nápoles have become a tourist attraction, advertized by the water and theme park and celebrated with statues and signs by local businesses in Doradal, seemingly to appeal to tourists. Residents have become accustomed to seeing hippopotamuses walking within the city limits in the evenings. Further research is needed to adequately characterize people's perceptions of the species in Colombia and their assessment of the costs and benefits associated with the introduction.

\section{Discussion}

The middle Magdalena River basin is in the nascent stages of the introduction of a non-native megaherbivore, but little is as yet known beyond anecdotal information about the current status of the population and its potential ecological and social effects (Dembitzer, 2017). Research is required to document this novel occurrence, to contextualize it within the current scientific understanding of introduced species and human-wildlife interactions, and to inform resource managers and local stakeholders confronting the realities of this introduction. We offer three recommendations for further study.

Firstly, we need a better understanding of the current and predicted future population size. The estimates we have 
provided, which span an order of magnitude, are based upon anecdotal accounts of the current population size. A comprehensive survey is required, to refine this estimate. We also need more information on life history characteristics of this population (age at maturity, fecundity and mortality), to improve population growth estimates, and on the potential fitness costs of inbreeding depression, given the small founding population of four individuals, with only one male (Huisman et al., 2016). These data would facilitate predictions of population growth under different management scenarios and help resource managers determine the best response to this introduction.

Secondly, coincident with the population survey, the current range of the species needs to be confirmed. The characteristics of potential habitat for hippopotamuses could be used to develop a habitat suitability map for prediction of the geographical spread of the species. Together, these tools could allow researchers and environmental authorities to determine the likelihood of the potential expansion of the hippopotamus into other regions and countries.

Thirdly, a study is needed of the ecological and socioeconomic effects that the species is already having and may have in the future. This introduction provides a unique opportunity to examine how hippopotamuses may influence ecological functions through provision of resource subsidies to aquatic ecosystems, alteration of terrestrial and aquatic vegetation communities through grazing and disturbance, and influence on riparian and hydrological connectivity. We also need to identify any native flora and fauna that could be sensitive to the effects of the species' presence, to understand potential effects on humans and their livelihoods, and to predict and mitigate negative interactions between humans and hippopotamuses. The latter will require an understanding of people's perceptions of risk and engagement in participatory planning for any interventions (Treves et al., 2006).

The introduction of novel species can have major ramifications for native ecosystems and the human populations that depend upon these ecosystems. There are already a number of non-native mammal species in Colombia, several of which are considered invasive (Ramírez-Chaves et al., 2011). These species can impact native biodiversity directly and managing them draws limited funding away from conservation of native species. In South America the introduced beaver Castor canadensis, for example, has altered large areas of native forest and led to changes in species composition and ecosystem function (Anderson et al., 2006; Anderson \& Rosemond, 2007); the introduction of the hippopotamus could have similar effects on native habitats in Colombia.

Alternatively, in a time of global defaunation, the establishment of a new megaherbivore population could have benefits (Dirzo et al., 2014; Lundgren et al., 2018). The introduction of the hippopotamus in Colombia may be a form of accidental rewilding, functionally replacing historically native megafaunal species that went extinct $>10,000$ years ago at the end of the Pleistocene (Dembitzer, 2017; Lundgren et al., 2018). It has been suggested there is potential for rewilding in South America because of the absence of megafauna, and megaherbivores in particular, compared to both prehistorical and historical baselines (Svenning \& Faurby, 2017), suggesting the hippopotamus could provide ecological functions that were lost with the extinction of taxonomically different but functionally similar species. In addition, the establishment of a robust hippopotamus population in South America could have conservation benefits, as hippopotamus populations in their native range of sub-Saharan Africa have, until recently, been declining (Lewison \& Oliver, 2008; Lewison \& Pluhacek, 2017). The potential costs and benefits of this introduction must be carefully weighed to determine the most appropriate response.

The eradication of an introduced species after it has become established can be difficult and expensive, and it is imperative to decide early in the introduction how the species will be handled, and then to properly fund the desired approach (Puth \& Post, 2005). The current policy is to halt the growth of the population, and ultimately relocate them from the wild, but not by culling. It is important to predict the future distribution of hippopotamuses in Colombia in response to current management approaches and the likely social and ecological effects across this range to inform the decision-making process sufficiently (Ricciardi et al., 2013; Jeschke et al., 2014). Consideration also must be taken of local perceptions of hippopotamuses and proposed methods of controlling their spread, to avoid conflict over proposed management actions (García-Llorente et al., 2008; Crowley et al., 2017). A complex confluence of history, culture and environment in Colombia have set the stage for this novel, and unintended, ecological introduction of hippopotamuses into the Magdalena River basin. Research and information sharing will be critical for management authorities as they navigate an array of potential social, ecological and financial concerns in their response to the introduction.

Acknowledgements Funding was provided by a grant from the National Geographic Society to EPA (W447-16) and by grants from the US National Science Foundation to DMP (DEB 1354053, 1753727). This is contribution no. 929 from the Southeast Environmental Research Center in the Institute of Water \& Environment at Florida International University. We thank colleagues in Colombia for sharing valuable information about introduced hippopotamuses, especially historical accounts, and A. Farah and G. Herrera for creating the map.

Author contributions Compilation of historical information and literature review: all authors; development of population estimate: AS, DP; writing: all authors.

\section{Conflicts of interest None.}

Ethical standards This research abided by the Oryx guidelines on ethical standards. 


\section{References}

Aldana, A.M., Beltrán, M., Torres-Neira, J. \& Stevenson, P.R. (2008) Habitat characterization and population density of brown spider monkeys (Ateles hybridus) in Magdalena Valley, Colombia. Neotropical Primates, 15, 46-50.

Anderson, C.B., Griffith, C.R., Rosemond, A.D., Rozzi, R. \& Dollenz, O. (2006) The effects of invasive North American beavers on riparian plant communities in Cape Horn, Chile: do exotic beavers engineer differently in sub-Antarctic ecosystems? Biological Conservation, 128, 467-474.

Anderson, C.B. \& Rosemond, A.D. (2007) Ecosystem engineering by invasive exotic beavers reduces in-stream diversity and enhances ecosystem function in Cape Horn, Chile. Oecologia, 154, 141-153.

Angarita, H., Wickel, A.J., Sieber, J., Chavarro, J., Maldonado Ocampo, J., Herrera-R., G. et al. (2018) Basin-scale impacts of hydropower development on the Mompós Depression wetlands, Colombia. Hydrology and Earth System Sciences, 22, 2839-2865.

Bakker, E.S., Pagès, J.F., Arthur, R. \& Alcoverro, T. (2016) Assessing the role of large herbivores in the structuring and functioning of freshwater and marine angiosperm ecosystems. Ecography, 39, 162-179.

Balcázar-Vargas, M.P., Rangel-Ch., J.O. \& Linares-C., E.L. (200o) Diversidad florística de la Serranía de las Quinchas, Magdalena Medio (Colombia). Caldasia, 22, 191-224.

Betancur, G.R., Giraldo, E.V. \& Suarez, A.U. (2016) Evaluation of the epididymal sperm quality in hippopotamus Hippopotamus amphibius (Artiodactyla: Hippopotamidae) located in the Medio Magdalena, Colombia. Acta Zoologica Mexicana, 32, 158-167.

Сномва, C. (2013) Factors affecting the Luangwa (Zambia) hippo population dynamic within its carrying capacity band-insights for better management. International Journal of Biodiversity and Conservation, 5, 109-121.

Cormagdalena (2007) Atlas Cuenca del Rio Grande de la Magdalena. Corporación Autónoma Regional del Río Grande de la Magdalena, Antioquia, Colombia.

Cormagdalena (2013) Caracterización Física, Demográfica, Social y Económica de los Municipios Ribereños de la Jurisdicción de la Corporación Autónoma Regional del Río Grande de la Magdalena. Corporación Autónoma Regional del Río Grande de la Magdalena, Antioquia, Colombia.

Courchamp, F., Fournier, A., Bellard, C., Bertelsmeier, C., Bonnaud, E., JeschKe, J.M. \& Russell, J.C. (2017) Invasion biology: specific problems and possible solutions. Trends in Ecology \& Evolution, 32, 13-22.

Crowley, S.L., Hinchliffe, S. \& McDonald, R.A. (2017) Conflict in invasive species management. Frontiers in Ecology and the Environment, 15, 133-141.

Dawson, J., Pillay, D., Roberts, P.J. \& Perissinotto, R. (2016) Declines in benthic macroinvertebrate community metrics and microphytobenthic biomass in an estuarine lake following enrichment by hippo dung. Scientific Reports, 6, 37359.

Dembitzer, J. (2017) The case for hippopotamuses in Colombia. Israel Journal of Ecology and Evolution, 63, 5-8.

Deutsch, C.J., Self-Sullivan, C. \& Mignucci-Giannoni, A. (2008) Trichechus manatus. IUCN Global Species Programme Red List Unit, Cambridge, UK. dx.doi.org/10.2305/IUCN.UK.2008. RLTS.T22103A9356917.en [accessed 21 February 2018].

Dirzo, R., Young, H.S., Galetti, M., Ceballos, G., IsaAc, N.J.B. \& Collen, B. (2014) Defaunation in the Anthropocene. Science, 345, 401-406.

Dutton, C.L., Subalusky, A.L., Hamilton, S.K., Rosi, E.J. \& Post, D.M. (2018) Organic matter loading by hippopotami causes subsidy overload resulting in downstream hypoxia and fish kills. Nature Communications, 11, 1951.

Ehrenfeld, J.G. (2010) Ecosystem consequences of biological invasions. Annual Review of Ecology, Evolution, and Systematics, $41,59-80$.

Eltringham, S.K. (1999) The Hippos: Natural History and Conservation. Cambridge University Press, Cambridge, UK.

Gallardo, B., Clavero, M., Sánchez, M.I. \& Vilà, M. (2016) Global ecological impacts of invasive species in aquatic ecosystems. Global Change Biology, 22, 151-163.

Galvis, G. \& Mojica, J.I. (2007) The Magdalena River fresh water fishes and fisheries. Aquatic Ecosystem Health \& Management, $10,127-139$.

García-Llorente, M., Martín-López, B., González, J.A., Alcorlo, P. \& Montes, C. (2008) Social perceptions of the impacts and benefits of invasive alien species: implications for management. Biological Conservation, 141, 2969-2983.

Grey, J. \& HARPER, D.M. (2002) Using stable isotope analyses to identify allochthonous inputs to Lake Naivasha mediated via the hippopotamus gut. Isotopes in Environmental and Health Studies $38,245-250$.

Guhl, E. (2016) Colombia: Bosquejo de su Geografía Tropical. Universidad de los Andes, Bogotá, Colombia.

Huisman, J., Kruuk, L.E.B., Ellis, P.A., Clutton-Brock, T. \& Pemberton, J.M. (2016) Inbreeding depression across the lifespan in a wild mammal population. Proceedings of the National Academy of Sciences of the United States of America, 113, 3585-3590.

Hurd, F.G.S. \& Bohórquez, C.I. (2000) Evaluando el estado de la biodiversidad: el caso de la avifauna de la Serranía de las Quinchas, Boyacá, Colombia. Caldasia, 22, 61-92.

Jacobs, S.M., Bechtold, J.S., Biggs, H.C., Grimm, N.B., Lorentz, S., MCClain, M.E. et al. (2007) Nutrient vectors and riparian processing: a review with special reference to African semiarid Savanna ecosystems. Ecosystems, 10, 1231-1249.

Jeschke, J.M., Bacher, S., Blackburn, T.M., Dick, J.T.A., Essl, F., Evans, T. et al. (2014) Defining the impact of non-native species. Conservation Biology, 28, 1188-1194.

Jiménez-Segura, L.F., Palacio, J. \& Leite, R. (2010) River flooding and reproduction of migratory fish species in the Magdalena River basin, Colombia. Ecology of Freshwater Fish, 19, 178-186.

Jimenez-Segura, L., Santamaria, D.R., López-Casas, S., Delgado, J., Valderrama, M. \& Gil, D.G. (2014) Ictiofauna y desarrollo del sector hidroeléctrico en la cuenca del río Magdalena-Cauca, Colombia. Biota Colombiana, 15, 3-25.

Jiménez-Segura, L.F., Galvis-Vergara, G., Cala-Cala, P., García-Alzate, C.A., López-Casas, S., Ríos-Pulgarín, M.I. et al. (2016) Freshwater fish faunas, habitats and conservation challenges in the Caribbean river basins of north-western South America. Journal of Fish Biology, 89, 65-101.

Kanga, E.M., Ogutu, J.O., OlfF, H. \& Santema, P. (2011) Population trend and distribution of the Vulnerable common hippopotamus Hippopotamus amphibius in the Mara Region of Kenya. Oryx, 45, 20-27.

Kanga, E.M., Ogutu, J.O., Piepho, H.-P. \& OlfF, H. (2012) Humanhippo conflicts in Kenya during 1997-2008: vulnerability of a megaherbivore to anthropogenic land use changes. Journal of Land Use Science, 7, 395-406.

Kanga, E.M., Ogutu, J.O., Piepho, H.-P. \& OlfF, H. (2013) Hippopotamus and livestock grazing: influences on riparian vegetation and facilitation of other herbivores in the Mara Region of Kenya. Landscape and Ecological Engineering, 9, 47-58.

Kodric-Brown, A. \& Brown, J.H. (2007) Native fishes, exotic mammals, and the conservation of desert springs. Frontiers in Ecology and the Environment, 5, 549-553. 
Laverde-R., O., Stiles, F.G. \& Múnera-R., C. (2005) Nuevos registros e inventario de la avifauna de la Serranía de las Quinchas, un área importante para la conservacion de las aves (AICA) en Colombia. Caldasia, 27, 247-265.

Laws, R.M. \& Clough, G. (1966) Observations on the reproduction in the hippopotamus (Hippopotamus amphibius Linn.). In Comparative Biology of Reproduction in Mammals, Symposia of the Zoological Society of London (ed. I.W. Rowlands), pp. 117-140. Academic Press, London, UK.

Lewison, R. \& Oliver, W. (2008) Hippopotamus amphibius. In The IUCN Red List of Threatened Species. dx.doi.org/10.2305/IUCN. UK.2008.RLTS.T10103A316379o.en [accessed 4 July 2014].

Lewison, R. \& Pluhacek, J. (2017) Hippopotamus amphibius. IUCN Global Species Programme Red List Unit, Cambridge, UK. iucnredlist.org/details/10103/o [accessed 13 February 2018].

Link, A., Stevenson, P. \& de Luna, A.G. (2015a) Brown spider monkey Ateles hybridus (I. Geoffroy Saint Hilaire, 1829). In Primates in Peril: The World's 25 Most Endangered Primates 2014-2016 (eds C. Schwitzer, R.A. Mittermeier, A.B. Rylands, F. Chiozza, E.A. Williamson, J. Wallis \& A. Cotton), pp. 74-75. IUCN SSC Primate Specialist Group, International Primatological Society, Conservation International, and Bristol Zoological Society, Arlington, USA.

Link, A., Valencia, L.M., Céspedes, L.N., Duque, L.D., Cadena, C.D. \& Di Fiore, A. (2015b) Phylogeography of the Critically Endangered brown spider monkey (Ateles hybridus): testing the riverine barrier hypothesis. International Journal of Primatology, $36,530-547$.

Lock, J.M. (1972) The effects of hippopotamus grazing on grasslands. Journal of Ecology, 60, 445-467.

Lundgren, E.J., Ramp, D., Ripple, W.J. \& Wallach, A.D. (2018) Introduced megafauna are rewilding the Anthropocene. Ecography, 41, 857-866.

Martin, R.B. (2005) Transboundary Species Project: Hippopotamus. Ministry of Environment and Tourism, Windhoek, Namibia.

Mascaro, J., Hughes, R.F. \& Schnitzer, S.A. (2012) Novel forests maintain ecosystem processes after the decline of native tree species. Ecological Monographs, 82, 221-228.

Masese, F.O., A brantes, K.G., Gettel, G.M., Boulllon, S., Irvine, K. \& MCClain, M.E. (2015) Are large herbivores vectors of terrestrial subsidies for riverine food webs? Ecosystems, 18, 686-706.

McCarthy, T.S., Ellery, W.N. \& Bloem, A. (1998) Some observations on the geomorphological impact of hippopotamus (Hippopotamus amphibius L.) in the Okavango Delta, Botswana. African Journal of Ecology, 36, 44-56.

Mojica-Figueroa, B.H., Arévalo-González, K., González, F.A. \& Murillo, J. (2014) Caracterización de la calidad del agua en sitios de preferencia del manatí antillano (Trichechus manatus) en la ciénaga de Paredes, Magdalena Medio, Santander, Colombia. Biota Colombiana, 15, 174-187.

Moore, J.W. (2006) Animal ecosystem engineers in streams. BioScience, 56, 237-246.

Mosepele, K., Moyle, P.B., Merron, G.S., Purkey, D.R. \& Mosepele, B. (2009) Fish, floods, and ecosystem engineers: aquatic conservation in the Okavango Delta, Botswana. BioScience, 59, 53-64.

Naiman, R.J. \& Rogers, K.H. (1997) Large animals and system level characteristics in river corridors. BioScience, 47, 521-529.

Pienaar, P., Van Wyk, M. \& Fairall, B. (1966) An experimental cropping scheme of hippopotami in the Letaba river of the Kruger National Park. Koedoe, 9, 1-33.
PINCH, G. (2004) Egyptian Mythology: a Guide to the Gods, Goddesses, and Traditions of Ancient Egypt. Oxford University Press, New York, USA.

Post, A.W.C.H.M. (2000) The Hippopotamus: Nothing but a Nuisance? Hippo-Human Conflicts in Lake Victoria Area, Kenya. University of Amsterdam, Amsterdam, The Netherlands.

Puth, L.M. \& Post, D.M. (2005) Studying invasion: have we missed the boat? Ecology Letters, 8, 715-721.

Ramírez-Chaves, H.E., Ortega-Rincón, M., Pérez, W.A. \& Marín, D. (2011) Historia de las especies de mamíferos exóticos en Colombia. Boletín Científico. Centro de Museos. Museo de Historia Natural, 15, 139-156.

Restrepo, J.D. \& Escobar, H.A. (2018) Sediment load trends in the Magdalena river basin (1980-2010): anthropogenic and climate-induced causes. Geomorphology, 302, 76-91.

Restrepo, J.D., Kjerfye, B., Hermelin, M. \& Restrepo, J.C. (2006) Factors controlling sediment yield in a major South American drainage basin: the Magdalena River, Colombia. Journal of Hydrology, 316, 213-232.

Ricciardi, A., Hoopes, M.F., Marchetti, M.P. \& Lockwood, J.L. (2013) Progress toward understanding the ecological impacts of nonnative species. Ecological Monographs, 83, 263-282.

Sandoval-H, J., Gomez, J.P. \& Cadena, C.D. (2016) Is the largest river valley west of the Andes a driver of diversification in Neotropical lowland birds? The Auk, 134, 168-180.

Schlaepfer, M.A., Sax, D.F. \& Olden, J.D. (2011) The potential conservation value of non-native species. Conservation Biology, 25, 428-437.

Smuts, G. \& Whyte, I. (1981) Relationships between reproduction and environment in the hippopotamus Hippopotamus amphibius in the Kruger National Park. Koedoe, 24, 169-185.

Stears, K., McCauley, D.J., Finlay, J.C., Mpemba, J., Warrington, I.T., Mutayoba, B.M. et al. (2018) Effects of the hippopotamus on the chemistry and ecology of a changing watershed. Proceedings of the National Academy of Sciences, 115, E5028-E5037.

Subalusky, A.L., Dutton, C.L., Rosi-Marshall, E.J. \& Post, D.M. (2015) The hippopotamus conveyor belt: vectors of carbon and nutrients from terrestrial grasslands to aquatic systems in sub-Saharan Africa. Freshwater Biology, 60, 512-525.

Subalusky, A.L., Dutton, C.L., Njoroge, L., Rosi, E.J. \& Post, D.M. (2018) Organic matter and nutrient inputs from large wildlife influence ecosystem function in the Mara River, Africa. Ecology, 99, 2558-2574.

Svenning, J.-C. \& Faurby, S. (2017) Prehistoric and historic baselines for trophic rewilding in the Neotropics. Perspectives in Ecology and Conservation, 15, 282-291.

Svenning, J.-C., Pedersen, P.B.M., Donlan, C.J., Ejrnæs, R., Faurby, S., Galetti, M. et al. (2016) Science for a wilder Anthropocene: synthesis and future directions for trophic rewilding research. Proceedings of the National Academy of Sciences, 113, 898-906.

Treves, A., Wallace, R.B., Naughton-Treves, L. \& Morales, A. (2006) Co-managing human-wildlife conflicts: a review. Human Dimensions of Wildlife, 11, 383-396.

Werner, P., CoWie, I. \& CUSACK, J.S. (2006) Juvenile tree growth and demography in response to feral water buffalo in savannas of northern Australia: an experimental field study in Kakadu National Park. Australian Journal of Botany, 54, 283-296.

Wolanski, E. \& Gereta, E. (1999) Oxygen cycle in a hippo pool, Serengeti National Park, Tanzania. African Journal of Ecology, $37,419-423$. 